\title{
The fate of arsenic adsorbed on iron oxides in the presence of arsenite- oxidizing bacteria
}

\author{
Zhennan Zhang a, b, Naiyi Yin ${ }^{\text {a, b }}$, Huili Du ${ }^{\text {a, b }}$, Xiaolin Cai ${ }^{\text {a, b }}$, Yanshan Cui a, b, * \\ ${ }^{a}$ College of Resources and Environment, University of Chinese Academy of Sciences, Huaibei Village 380, Huaibei Town, Huairou District, Beijing, 101408, \\ People's Republic of China \\ ${ }^{\mathrm{b}}$ Research Center for Eco-environmental Sciences, Chinese Academy of Sciences, Shuangqing Road 18, Haidian District, Beijing, 100085, People's Republic of \\ China
}

\section{H I G H L I G H T S}

- Microbial cells lowered total As adsorption by minerals.

- Microbial oxidation proceeded much slowly in solid phase than in aqueous phase.

- Minerals with a higher affinity for As(III), hindered As(III) oxidation more.

- Under aerobic conditions, $\mathrm{As}(\mathrm{V})$ is the primary form in solid and aqueous phases.

\section{A R T I C L E I N F O}

\section{Article history:}

Received 22 August 2015

Received in revised form

31 January 2016

Accepted 16 February 2016

Available online 15 March 2016

Handling Editor: X. Cao

\section{Keywords:}

Arsenic

Iron oxide

Arsenite-oxidizing bacteria

\begin{abstract}
A B S T R A C T
Arsenic (As) is a redox-active metalloid whose toxicity and mobility in soil depend on its oxidation state. Arsenite $[\mathrm{As}(\mathrm{III})]$ can be oxidized by microbes and adsorbed by minerals in the soil. However, the combined effects of these abiotic and biotic processes are not well understood. In this study, the fate of arsenic in the presence of an isolated As(III)-oxidizing bacterium (Pseudomonas sp. HN-1, $10^{9}$ colonyforming units (CFUs) $\cdot \mathrm{ml}^{-1}$ ) and three iron oxides (goethite, hematite, and magnetite at $1.6 \mathrm{~g} \mathrm{~L}^{-1}$ ) was determined using batch experiments. The total As adsorption by iron oxides was lower with bacteria present and was higher with iron oxides alone. The total As adsorption decreased by $78.6 \%, 36.0 \%$ and 79.7\% for goethite, hematite and magnetite, respectively, due to the presence of bacteria. As(III) adsorbed on iron oxides could also be oxidized by Pseudomonas sp. $\mathrm{HN}-1$, but the oxidation rate $\left(1.3 \mu \mathrm{mol} \mathrm{h}^{-1}\right)$ was much slower than the rate in the aqueous phase $\left(96.2 \mu \mathrm{mol} \mathrm{h}^{-1}\right)$. Therefore, the results of other studies with minerals only might overestimate the adsorptive capacity of solids in natural systems; the presence of minerals might hinder As(III) oxidation by microbes. Under aerobic conditions, in the presence of iron oxides and As(III)-oxidizing bacteria, arsenic is adsorbed onto iron oxides within the adsorption capacity, and $\mathrm{As}(\mathrm{V})$ is the primary form in the solid and aqueous phases.
\end{abstract}

() 2016 Elsevier Ltd. All rights reserved.

\section{Introduction}

The elevated and extensive contamination of arsenic (As) in soil and groundwater causes serious health risks in many regions around the globe (Smith et al., 1998; Smedley and Kinniburgh, 2002). The toxicity and mobility of As in soil depend on its chemical speciation. Inorganic forms are more toxic than organic forms, and arsenite( $\mathrm{As}(\mathrm{III}))$ is generally regarded as more mobile and more

\footnotetext{
* Corresponding author.

E-mail address: cuiyanshan@ucas.ac.cn (Y. Cui).
}

toxic than arsenate $(\mathrm{As}(\mathrm{V}))$ (WorldHealthOrganization, 1981; Liu et al., 2001). The environmental and toxicological effects of As are related to the valence states and distribution between the immobile and mobile forms (Cullen and Reimer, 1989; Langner and Inskeep, 2000). Therefore, As oxidation and distribution in soil affect its remediation and human health risk assessment. Arsenic oxidation is kinetically slow with atmospheric oxygen; therefore, it is believed that soil components, including minerals and microbes, contribute to As(III) oxidation in oxic soil (Eary and Janet, 1990).

Microbial oxidation is an important factor that influences the fate of As in soil. More than 30 strains representing at least nine genera have been reported, including $\alpha-, \beta-, \gamma$-Proteobacteria. They 
include chemoautotrophic As(III) oxidizers and heterotrophic As(III) oxidizers (Oremland and Stolz, 2003). For chemoautotrophic As(III) oxidizers, the oxidation of As(III) generates energy, which promotes growth and proliferation (Santini et al., 2000). For heterotrophic As(III) oxidizers, the oxidation of As(III) is described as a detoxification mechanism catalyzed by the periplasmic enzyme arsenite oxidase (Muller et al., 2003). Diverse As(III) oxidation bacteria have not only been found in As-contaminated soils (Cai et al., 2009), but also in low As-containing soil (Bahar et al., 2012).

Soil minerals, especially iron(hydr) oxides, are considered important solid phases, which are responsible for As mobilization or immobilization in soils and sediments (Daus et al., 1998; Frommer et al., 2011). Goethite, hematite and magnetite, which are widespread in soils (Schwertmann and Cornell, 1991), have been found to be effective adsorbents of $\mathrm{As}(\mathrm{III})$ and $\mathrm{As}(\mathrm{V})$ (Arai et al., 2004; Ona-Nguema et al., 2005; Lakshmipathiraj et al., 2006; Gimenez et al., 2007; Ohe et al., 2010). Many studies were carried out to study the characteristics and mechanisms of As adsorption onto goethite, hematite and magnetite (Ona-Nguema et al., 2005; Gimenez et al., 2007). Gimenez et al. observed the highest As(III) sorption on the hematite surface over the entire $\mathrm{pH}$ range compared to goethite and magnetite (Gimenez et al., 2007). Iron(hydr) oxides could only slightly oxidize As(III), when they were induced or catalyzed, for example, by Fe(II) or light. Early studies showed the rapid oxidation of $\mathrm{As}(\mathrm{III})$ to $\mathrm{As}(\mathrm{V})$ at the surface of goethite, magnetite and ferrihydrite in $\mathrm{Fe}(\mathrm{II})$-mediated reactions (Amstaetter et al., 2010; Ona-Nguema et al., 2010). It is reported that goethite interacting with dissolved Fe(II) produced the highest redox activity compared with other Fe(III) (oxy)hydroxides (Elsner et al., 2004). Photoinduced oxidation of As(III) by goethite has also been reported and can be significantly restricted by humic acid (Bhandari et al., 2012; Wang et al., 2013).

Minerals and microbes in soils influence As by adsorption, oxidation or reduction; thus, the interaction between these abiotic and biotic processes must be determined. The combined effects of bacteria and Mn oxides were investigated. It was shown that As(III) was oxidized most rapidly in a mixed cell- $\mathrm{MnO}_{2}$ system, although the total sorption of As on minerals was lower (Jones et al., 2012). The microbial reduction of $\mathrm{As}(\mathrm{V})$ in the presence of iron oxides was also analyzed. Huang et al. suggested that the attachment of microbial cells to mineral surfaces promoted $\mathrm{As}(\mathrm{V})$ desorption, thereby facilitating $\mathrm{As}(\mathrm{V})$ reduction (Huang et al., 2011b). From a different perspective, Langner et al. indicated that sorbed $\mathrm{As}(\mathrm{V})$ could only be slightly reduced. Therefore, the desorption of As(V) was too slow to cause an increase in the aqueous content (Langner and Inskeep, 2000). Above all, the combined oxidation of bacteria and Mn oxides, and microbial reduction in the presence of iron oxides have been reported in earlier studies. However, with the coexistence of iron(hydr)oxides and As(III)-oxidizing bacteria in soil, the As oxidation and adsorption processes remain poorly understood.

In the present study, the mixed cell-iron oxide batch experiments were used, and the objectives of the study were to investigate (1) the adsorption by iron oxides in the presence of As(III)oxidizing bacteria, (2) the As(III) oxidation by As(III)-oxidizing soil bacteria in the presence of iron oxides (goethite, hematite and magnetite) and (3) the distribution of As(III) and As (V) between solution and iron oxides after treatment with As(III)-oxidizing soil bacteria.

\section{Materials and methods}

\subsection{Iron oxides synthesis and characterization}

The experiments were conducted with three iron oxides: goethite, hematite and magnetite. Goethite and hematite were synthesized by the method of Schwertmann and Cornell (Schwertmann and Cornell, 1991). Magnetite was synthesized by the method of Jolivet and Tronc (Jolivet and Tronc, 1988). These iron oxides were washed repeatedly with double-distilled water until they were free of excess salt; then, they were freeze-dried. The iron oxides were identified by X-ray diffraction (XRD) using an X-ray powder diffractometer(X'Pert PRO MPD diffractometer) with $\mathrm{Cu} \mathrm{K} \alpha$ radiation and scanned from $10^{\circ}$ to $80^{\circ} 2 \theta$ with a continuous scan rate of $0.025^{\circ} / 18 \mathrm{~s}$. The surface area of goethite, hematite and magnetite was $36.8 \pm 1.3,22.0 \pm 0.3$, and $67.5 \pm 0.3 \mathrm{~m}^{2} \mathrm{~g}^{-1}$, respectively, based on 5-point $\mathrm{N}_{2}$-BET measurements (Micromeritics Gemini V 2.0, U.S.)

\subsection{The isolation and identification of As(III)-oxidizing bacteria}

A soil sample $\left([\right.$ As $]=284 \mathrm{mg} \mathrm{kg}^{-1}$ ) collected from mine of Zhuzhou, Hunan, China, was used as an inoculum for enrichment culture. The isolation and subsequent growth experiments were carried out with a modified chemically defined medium (CDM) (8.12 $\mathrm{mM} \quad \mathrm{MgSO}_{4}, \quad 18.7 \mathrm{mM} \quad \mathrm{NH}_{4} \mathrm{Cl}, \quad 7 \quad \mathrm{mM} \quad \mathrm{Na}_{2} \mathrm{SO}_{4}$, $0.0574 \mathrm{mM} \mathrm{K}_{2} \mathrm{HPO}_{4}, 0.457 \mathrm{mM} \mathrm{CaCl}, 44.6 \mathrm{mM}$ Na-lactate and $9.5 \mathrm{mM} \mathrm{NaHCO}$, with the pH adjusted to 7.0) as described by Weeger et al. (1999). As-resistant bacteria were enriched with $1.33 \mathrm{mM}$ As(III) under oxic incubation. After enrichment, samples were serially diluted, and a cell suspension was spread onto CDM plates with $1.33 \mathrm{mM}$ As(III) to obtain single colonies. A pure culture was obtained by successive isolation of colonies in As(III)supplemented medium. The ability of the obtained As-resistant bacteria to oxidize $\mathrm{As}(\mathrm{III})$ was tested using a qualitative $\mathrm{AgNO}_{3}$ screening method as described by Liao et al. (2011).

Bacterial genomic DNA of the obtained As(III)-oxidizing bacterium was extracted using TIANamp Bacteria DNA Kit (TIANGEN, China) following the manufacturer's instructions. Then, the bacterial 16S rDNA gene was amplified using universal primers, $27 \mathrm{f}$ and 1492r (Lane, 1991). Cells in late exponential growth phase were inoculated in CDM in subsequent batch experiments.

\subsection{Batch oxidation and adsorption experiments}

\subsubsection{Arsenic adsorption in the presence of bacteria}

Arsenic adsorption by iron oxides (goethite, hematite and magnetite) in the presence of bacteria was studied. The experimental group is named the cell-iron oxide group in the following sections. Abiotic control experiments of iron oxides only were also conducted, which is named the mineral-only group in the following sections.

Experiments were carried out in triplicate using sterile Erlenmeyer flasks with $100 \mathrm{ml}$ CDM. The reaction was initiated by adding $\mathrm{As}(\mathrm{III})\left(\mathrm{NaAsO}_{2}\right)(600 \mu \mathrm{M})$, cell cultures $\left(10^{9} \mathrm{CFU} \mathrm{ml}^{-1}\right)$ and iron oxides $\left(1.6 \mathrm{~g} \mathrm{~L}^{-1}\right)$, with a constant ionic strength $(0.1 \mathrm{M} \mathrm{NaCl})$. The initial As concentration was chosen to reach adsorption saturation. The flasks were shaken at $25{ }^{\circ} \mathrm{C}$ at $150 \mathrm{rpm}$ for $24 \mathrm{~h}$. During the experiments, $2 \mathrm{ml}$ samples were removed periodically from the flasks and passed through a $0.22-\mu \mathrm{m}$ filter. The concentrations of total dissolved As were determined using inductively coupled plasma optical emission spectrometry (ICP-OES, OPTIMA 8300, U.S.). Then, the amount of adsorbed As was calculated by subtracting the dissolved As from the total As.

\subsubsection{Effect of contact order of bacteria and goethite on the oxidation and adsorption of As}

Three groups of cell-goethite batch experiments of different contact order of bacteria and goethite were used for the experiments: (1) bacteria, goethite and As(III) were added simultaneously 
(abbreviated SBAG); (2) bacteria and As(III) were incubated for $1 \mathrm{~h}$ before goethite was added (abbreviated BAG); and (3) goethite and As(III) were incubated for $1 \mathrm{~h}$ before bacteria were added (abbreviated $G A B)$.

Experiments were carried out in triplicate using sterile Erlenmeyer flasks with $100 \mathrm{ml} \mathrm{CDM}$. The reaction was initiated by adding As(III) $\left(\mathrm{NaAsO}_{2}\right)(160 \mu \mathrm{M})$, cell cultures $\left(10^{9} \mathrm{CFU} \mathrm{ml}{ }^{-1}\right)$ and goethite $\left(1.6 \mathrm{~g} \mathrm{~L}^{-1}\right)$, with a constant ionic strength $(0.1 \mathrm{M} \mathrm{NaCl})$. The concentration of $\mathrm{As}(\mathrm{III})$ and goethite were chosen to ensure that the ratio of $\mathrm{As}$ to $\mathrm{Fe}(\mathrm{Fe} / \mathrm{As} \approx 100)$ after incubation was appropriate for the determination of the ratio of $\mathrm{As}(\mathrm{III})$ and $\mathrm{As}(\mathrm{V})$ by XANES analysis. In other studies on $\mathrm{As}(\mathrm{III})$ oxidation in the presence of iron oxides, the Fe/As ratio ranged from 5 to 580 (Ona-Nguema et al., 2005, 2010; Bhandari et al., 2011, 2012). The flasks were shaken at $25^{\circ} \mathrm{C}$ at $150 \mathrm{rpm}$ for $10 \mathrm{~h}$. The adsorption reached equilibrium in $10 \mathrm{~h}$. Abiotic control experiments of goethite only were also conducted. During the experiments, $2 \mathrm{ml}$ samples were removed periodically from the flasks, passed through a $0.22-\mu \mathrm{m}$ filter, and stored at $-80^{\circ} \mathrm{C}$ until As speciation analysis. At the end of the reaction, the incubation suspensions were centrifuged, washed twice and then freeze dried for arsenic XANES analysis.

\subsubsection{Comparison of As(III) oxidation in three cell-iron oxide systems}

Batch experiments for microbial oxidation in the presence of three iron oxides were conducted to determine the apparent As(III) oxidation and the proportion of $\mathrm{As}(\mathrm{III})$ to $\mathrm{As}(\mathrm{V})$ in the solid phase. Three mixed cell-iron oxide batch experiments were conducted using Pseudomonas sp. HN-1 with hematite, goethite (SBAG group) and magnetite, separately. Abiotic control experiments of iron oxides only were also conducted.

Experiments were carried out under the same conditions as those given in 2.3.2.

\subsection{Arsenic speciation analysis}

Arsenic speciation was determined by HPLC-ICP-MS (7500a; Agilent Technologies) as described in the literature (Zhu et al., 2008). Chromatographic columns were obtained from Hamilton and consisted of a precolumn ( $11.2 \mathrm{~mm}, 12-20 \mu \mathrm{m})$ and a PRP-X100 $10-\mu \mathrm{m}$ anion-exchange column $(250 \times 4.1 \mathrm{~mm})$. The mobile phase consisted of $10 \mathrm{mM}$ diammonium hydrogen phosphate $\left(\left(\mathrm{NH}_{4}\right)_{2} \mathrm{HPO}_{4}\right)$ and $10 \mathrm{mM}$ ammonium nitrate $\left(\mathrm{NH}_{4} \mathrm{NO}_{3}\right)$, adjusted to $\mathrm{pH} 6.2$ using nitric acid. The mobile phase was pumped through the column isocratically at $1 \mathrm{ml} \mathrm{min}^{-1}$. Arsenic species in the samples were identified by comparing their retention time with those of the standards, including arsenite ( $\mathrm{As}(\mathrm{III}))$ and arsenate $(\mathrm{As}(\mathrm{V}))$, and quantified by external calibration curves with peak areas.

\subsection{Arsenic XANES (K-edge) analysis}

The As K-edge XANES spectra of the solid samples were collected on beamline 1W2B at the Beijing Synchrotron Radiation Facility (BSRF), China. The electron beam energy was $2.5 \mathrm{GeV}$, with a maximum beam current of $250 \mathrm{~mA}$. Arsenic K-edge XANES spectra were collected at room temperature in the fluorescence mode for the samples and transmission mode for the reference materials. Data analysis was conducted using Athena software. Every sample was normalized, and linear combination fitting (LCF) was then used to identify the As species. Reference materials included $\mathrm{As}(\mathrm{III})$-adsorbed goethite, $\mathrm{As}(\mathrm{V})$-adsorbed goethite (OnaNguema et al., 2010), arsenite and arsenate. The accuracy of the $\operatorname{As}(\mathrm{III}) / \Sigma$ As ratio is $\pm 2 \%$, and components contributing less than $5 \%$ are not statistically significant (Morin et al., 2003).

\subsection{FESEM analysis}

Iron oxides (goethite, hematite, and magnetite) and batch reaction products, including mixed cell-goethite, cell-hematite, and cell-magnetite samples were imaged by field-emission scanning electron microscopy (FESEM). Samples of batch reaction products were centrifuged and fixed with $2.5 \%$ glutaraldehyde at $4{ }^{\circ} \mathrm{C}$. Then, they were washed with phosphate buffer three times. Samples were dehydrated with alcohol, and dried with liquid $\mathrm{CO}_{2}$ using the critical point method. Finally, samples were imaged using a Hitachi FESEM with a $3 \mathrm{kV}$ accelerating voltage and working distances of $8.3-8.7 \mathrm{~mm}$.

\section{Results and discussion}

\subsection{Isolation and identification of Pseudomonas sp. HN-1}

An aerobic heterotrophic bacterial strain was isolated. BLAST and similarity analysis of the near full length 16S rRNA gene sequences (1,465 bp) of the As(III)-oxidizing bacterium showed that it belonged to Pseudomonas (99\% similarity, GeneBank accession number: KJ452337). The bacterial strain was named as Pseudomonas sp. HN-1. The strain cannot grew in media designed for chemolithotrophic metabolism using As(III) as the sole electron donor and it requires an organic carbon source (e.g., sodium lactate) for growth. With the result that As(III) oxidation corresponded with microbial growth (data not shown), it is suggested that the mechanism of $\mathrm{As}$ (III) oxidation by the isolate was related to As detoxification rather than energy generation (Oremland and Stolz, 2005).

\subsection{Arsenic adsorption in the presence of bacteria}

Arsenic adsorption by hematite, goethite, and magnetite with or without $\mathrm{As}$ (III)-oxidizing bacteria during the incubation is shown in Fig. 1. In the cell-iron oxide groups and the mineral-only groups, the maximum As adsorption by hematite was higher than that by goethite and magnetite. The abiotic mineral studies of Gimenez et al. showed higher As adsorption by natural hematite than natural goethite and magnetite (Gimenez et al., 2007). It is reported that As(III) forms different inner-sphere surface complexes for hematite and goethite (Ona-Nguema et al., 2005).

In our study, for the cell-iron oxide group, after $10 \mathrm{~h}$ of incubation, the adsorption amount of As was 34.4, 255.3, and $37.3 \mu \mathrm{mol} \mathrm{g}^{-1}$ by goethite, hematite and magnetite, respectively. However, for the mineral-only group, the adsorption amount of As was $160.4,398.6$ and $183.6 \mu \mathrm{mol} \mathrm{g}^{-1}$ by these three minerals, respectively. Total As adsorption decreased by $78.6 \%, 36.0 \%$ and $79.7 \%$ for these three cell-iron oxide groups compared with corresponding mineral-only groups, respectively (Fig. 1). A lower amount of As was adsorbed by cell-iron oxide batch experiments than by minerals alone. The reduced adsorption may result from mineral surface passivation by extracellular polymeric substances (EPS), which contain phosphate and carboxylate groups that could compete with As for adsorption sites (Huang et al., 2011a). It was reported that the adsorption of $\mathrm{As}(\mathrm{V})$ and $\mathrm{As}(\mathrm{III})$ strongly decreased with increasing addition of EPS for ferrihydrite, goethite and hematite (Huang et al., 2011a). EPS play an important role during the adhesion of bacteria to minerals. Covalent bond formations during the adsorption of EPS from bacteria and Fe-oxy(hydr)oxides have been demonstrated (Omoike and Chorover, 2006; Fang et al., 2012). However, the functions of EPS for different minerals are not always the same. In the absence of EPS, the adhesion of bacteria to clay minerals was reduced, but adhesion to goethite was enhanced (Hong et al., 2013).

The images of mixed cell-iron oxide after the batch experiments 


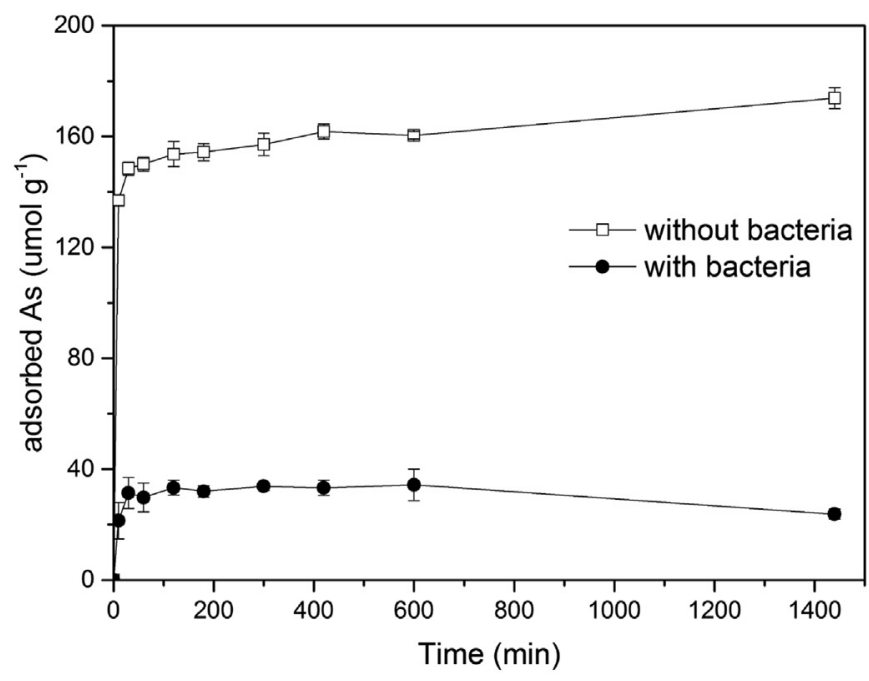

(a)

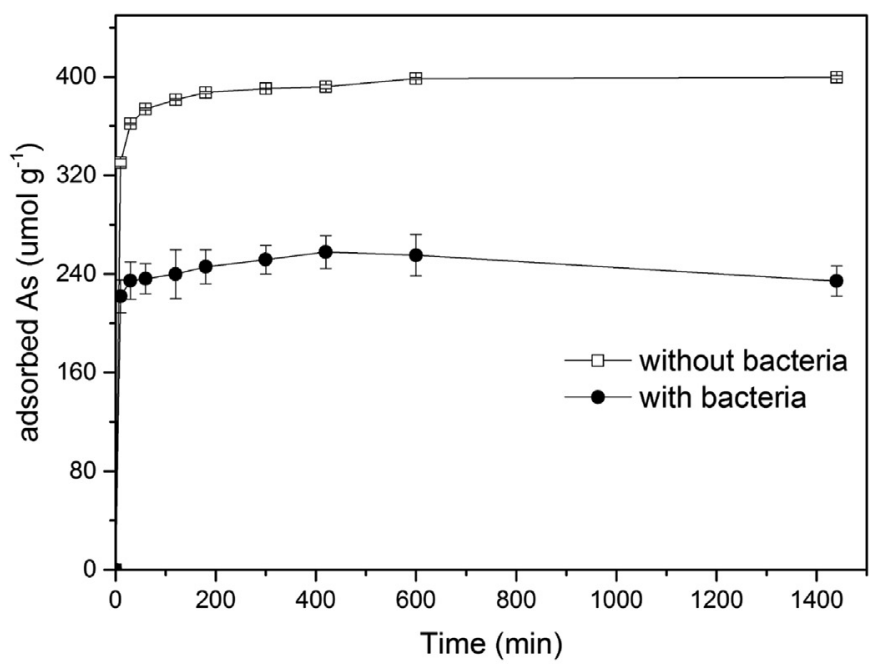

(b)

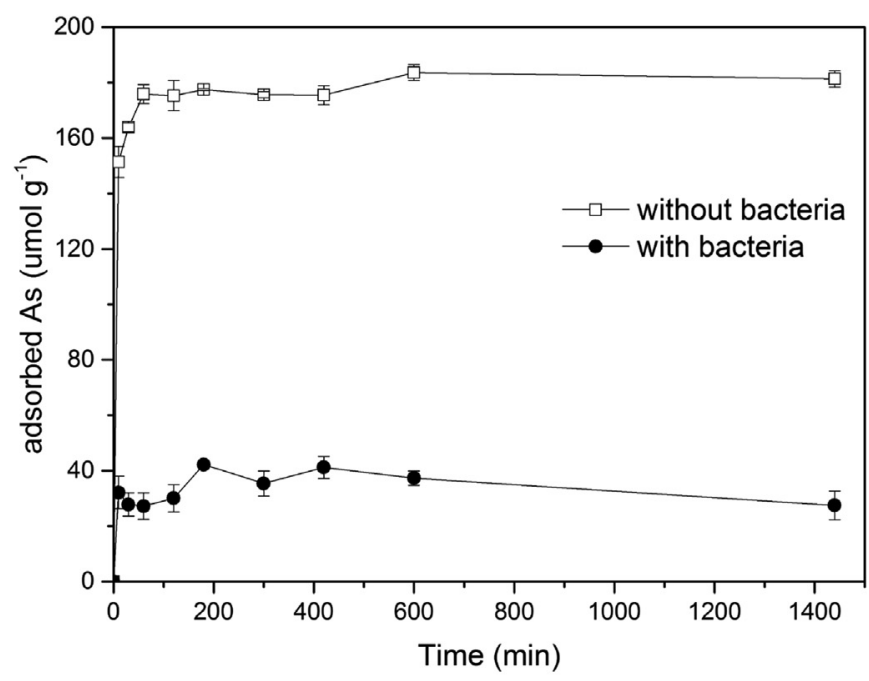

(c)

Fig. 1. Adsorbed As by (a) goethite, (b) hematite and (c) magnetite during the incubation with or without bacteria. are shown in Fig. 2. The macroscopic results showed the attachment between bacteria and minerals. The adhesion of bacteria to minerals might block the adsorption sites of As on the minerals. Therefore, As adsorption might be impeded by bacteria due to occupation of adsorption sites. In addition, no morphological change in the iron oxides was observed after incubation with As and bacteria, which is similar to the observation in cell-Mn oxide oxidation by Jones et al (Jones et al., 2012). However, different morphologies were detected by Muehe et al. during microbial $\mathrm{Fe}(\mathrm{III})$ reduction, as revealed by the formation of secondary $\mathrm{Fe}$ mineral products (Muehe et al., 2013). In the study of Jones et al., it was observed that more As was adsorbed by $\delta-\mathrm{MnO}_{2}$ alone than by the cell- $\delta-\mathrm{MnO}_{2}$ experiments (Jones et al., 2012). It was proved that microbial cells and EPS could mobilize As from Fe(III)-hydroxides because of competitive interactions between adsorbed As and functional moieties of cell surface molecules and EPS at mineral surfaces (Huang et al., 2011a). Adsorption could be reduced due to surface passivation, as well as a decrease in oxidation and reduction by minerals. Parikh et al. indicated that the reaction rates were reduced when bacterial adhesion strongly passivated $\delta-\mathrm{MnO}_{2}$ and reduced the $A s($ III) interactions with the mineral surface (Parikh et al., 2010). It is proposed that $A s(V)$ adsorption could inhibit As(III) oxidation by blocking adsorption sites (Zhu et al., 2009).

Early studies indicated that the presence of organic matter (ions in solution) also influenced As(III) adsorption or oxidation by $\delta$ $\mathrm{MnO}_{2}$ by blocking reaction sites (Zhu et al., 2009; Parikh et al., 2010). Iron oxides and Mn oxides, as common soil minerals (Daus et al., 1998; Post, 1999), showed a similar tendency of adsorption in the presence of bacteria, which can partially reflect real conditions in soil. Therefore, mineral-only experiments might overestimate As adsorption by minerals in soils.

\subsection{Effect of contact order of bacteria and goethite on oxidation and adsorption of As}

Fig. S1 summarizes the As content in the aqueous phase at the end of incubation. The adsorption percentage of the control, SBAG, BAG and GAB was 99.97\%, 96.98\%, 96.26\% and 97.23\%, respectively. The amount of As adsorbed by goethite decreased in the following order: control > SBAG > BAG. The decrease of As adsorption was related to the exposure time of bacteria, providing additional evidence of the inhibiting effect of bacteria on As adsorption by minerals.

Synchrotron-based measurement of As speciation by XANES confirmed that most of the As was found in the solid phase in the form of $\mathrm{As}(\mathrm{V})$ after incubation (Fig. 3). The ratio of $\mathrm{As}(\mathrm{III})$ to total As after incubation decreased in the following order: GAB (27\%)> SBAG (6.1\%) > BAG (4.7\%) (Table 1). For group BAG, after a 1-h incubation of bacteria and As, most of $\mathrm{As}(\mathrm{III})$ was oxidized to $\mathrm{As}(\mathrm{V})$, and then adsorption occurred (Fig. 4(b)). However, for group GAB, after a 1-h incubation of goethite and As(III), most of the As(III) was adsorbed on the mineral surface, and then oxidation occurred there (Fig. 4(c)). Thus, the oxidation of As(III) primarily occurred in the aqueous phase for group BAG and in the solid phase for group GAB. Based on these results, 73\% of As(III) in solid phase was oxidized in $9 \mathrm{~h}\left(1.3 \mu \mathrm{mol} \mathrm{h}{ }^{-1}\right)$. The calculated oxidation rate was both around $1.3 \mu \mathrm{mol} \mathrm{h}^{-1}$ according to the proportion of $\mathrm{As}(\mathrm{V})$ in solid phase at $8 \mathrm{~h}$ and $10 \mathrm{~h}$, which is $65.7 \%$ and $82.4 \%$, respectively. However, in the absence of minerals, As(III) oxidation could be almost completed in $10 \mathrm{~min}$ in the aqueous phase $\left(96.2 \mu \mathrm{mol} \mathrm{h}^{-1}\right)$ (Fig. S2). Therefore, the oxidation rate is approximately 75 times faster in the aqueous phase than in solid phase by the As(III)-oxidizing bacterium, Pseudomonas sp. HN-1, indicating that the presence of minerals hindered microbial oxidation. For group SBAG, the proportion of $\mathrm{As}(\mathrm{III}) / \mathrm{As}(\mathrm{V})$ after incubation was closer to that of BAG than GAB. 


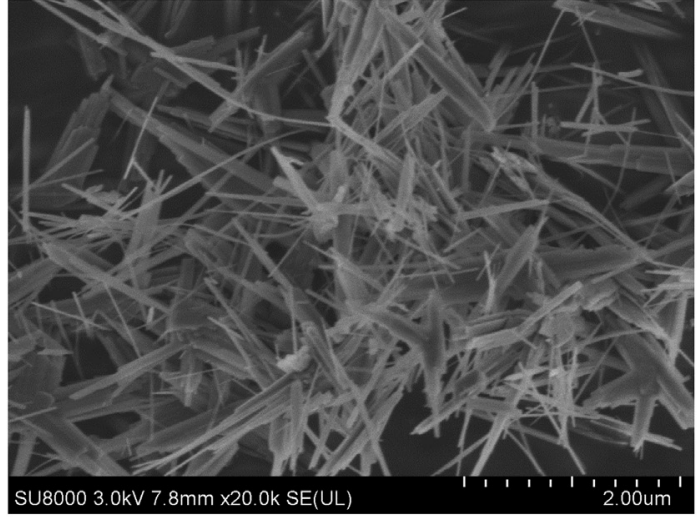

(a)

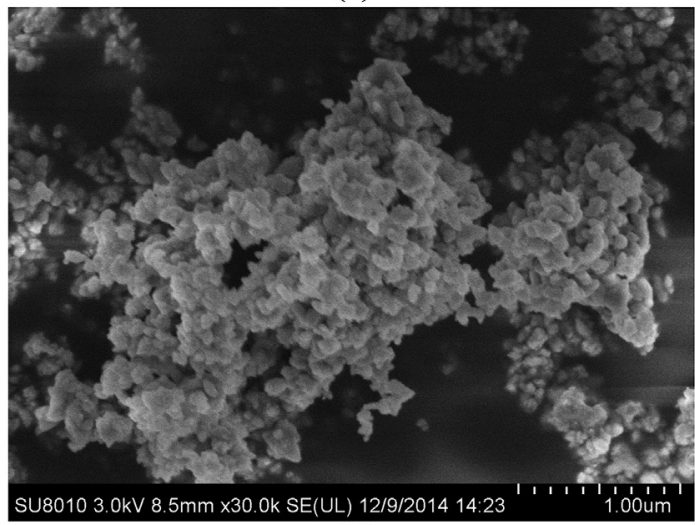

(c)

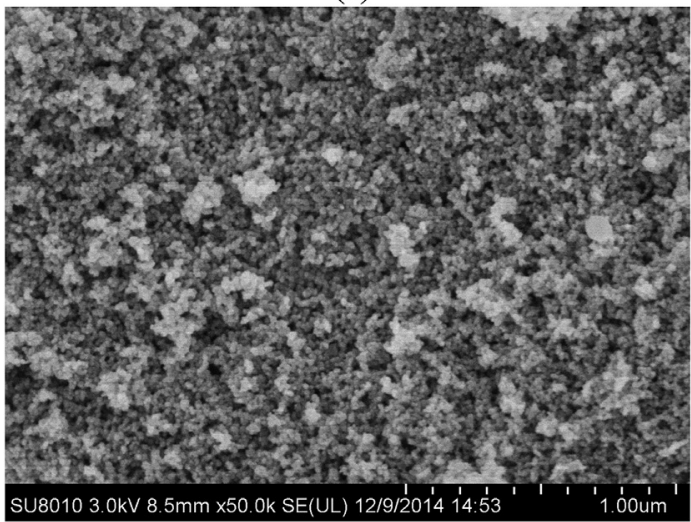

(e)

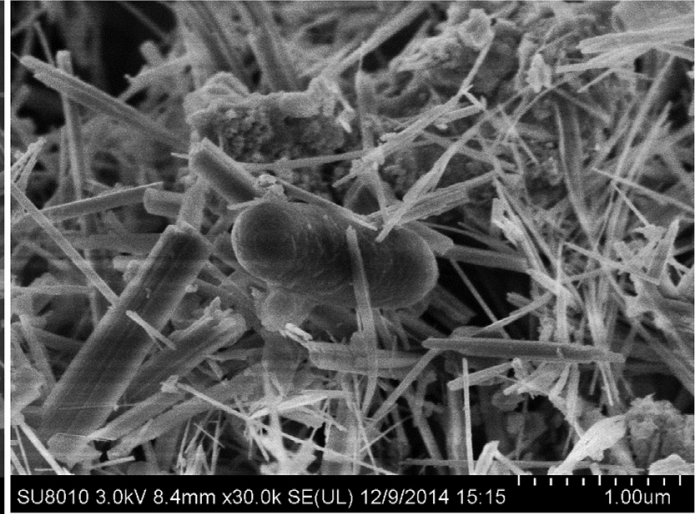

(b)

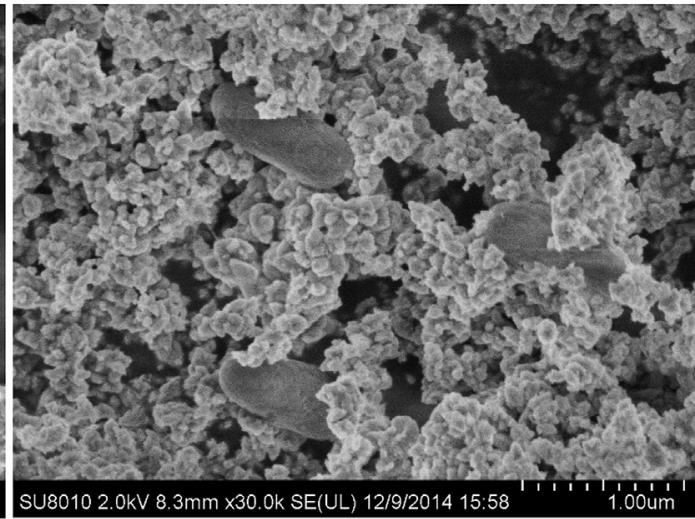

(d)

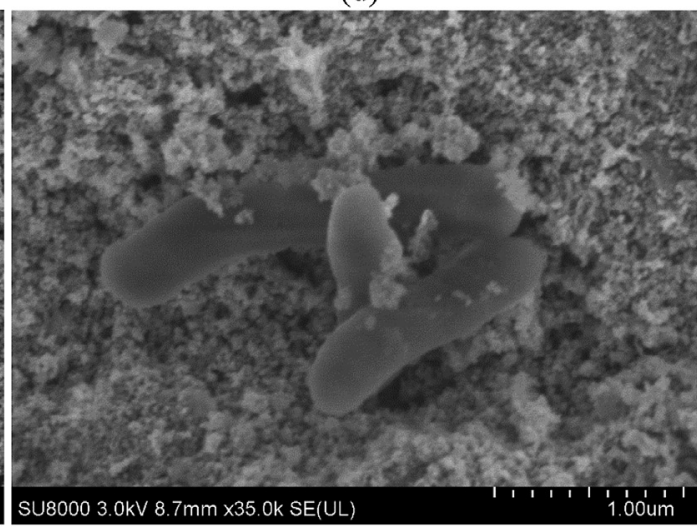

(f)

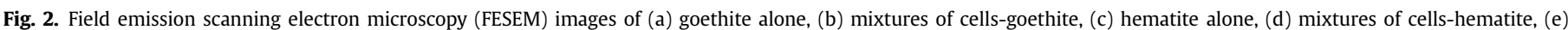
magnetite alone, (f) mixtures of cells-magnetite.

In another word, the oxidation and adsorption process in group SBAG was similar to the process in group BAG. Therefore, we suppose that $\mathrm{As}$ (III) oxidation took place faster than $\mathrm{As}(\mathrm{III})$ adsorption at this concentration of $\mathrm{As}(\mathrm{III})(160 \mu \mathrm{M})$ and cells $\left(10^{9} \mathrm{CFU} \mathrm{m}{ }^{-1}\right)$. In the case of microbial reduction, Huang et al. and Ohtsuka et al. indicated that the reduction of adsorbed $\mathrm{As}(\mathrm{V})$ is much slower than that of dissolved $\mathrm{As}(\mathrm{V})$ by $\mathrm{As}(\mathrm{V})$-reducing bacteria (Huang et al., 2011b; Ohtsuka et al., 2013). They demonstrated that the presence of minerals hindered microbial $\mathrm{As}(\mathrm{V})$ reduction. In the former study, a strong decrease in $\mathrm{As}(\mathrm{V})$ reduction rate was found as the solid concentration and the extent of $\mathrm{As}(\mathrm{V})$ sorption increased. The reduction rate was $10-78$ times faster in the aqueous phase than in solid phase based on different amounts of solid. In the latter study, the reduction rate was approximately 10 times faster in the aqueous phase than in the solid phase. Furthermore, Ohtsuka et al. has shown arsenic release from paddy soil by an arsenate-reducing bacterium Geobater sp. OR-1, due to the direct $\mathrm{As}(\mathrm{V})$ reduction in the solid phase. However, an $\mathrm{As}(\mathrm{V})$ - reducing bacteria, Clostridium sp. CN8, was observed to have the ability to only reduce $\mathrm{As}(\mathrm{V})$ in the aqueous phase, and could hardly reduce sorbed-As. A slight desorption of As from $\mathrm{Fe}$ (hydr)oxide was found by strain CN8 (Langner and Inskeep, 2000). These studies concentrated on Asiron oxide-As(V)-reducing bacteria systems. However, our studies focused on As-iron oxide-As(III)-oxidizing bacteria systems. To the best of our knowledge, no investigation of the As fate in the presence of As(III)-oxidizing bacteria and iron oxides has been reported. 


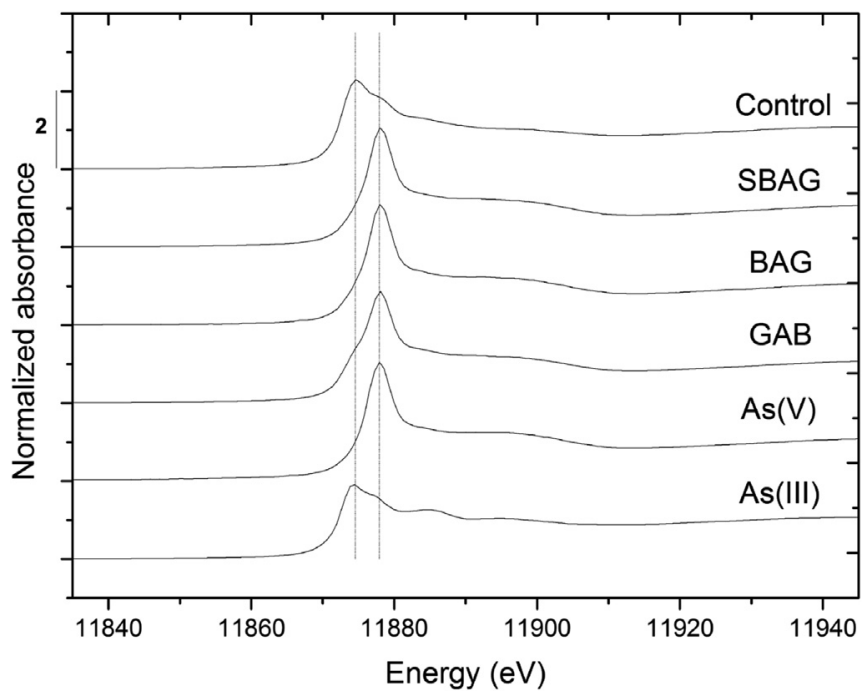

Fig. 3. Arsenic K-edge XANES data for $\mathrm{As}(\mathrm{III})$ and $\mathrm{As}(\mathrm{V})$ adsorbed onto goethite at the end of incubation $(\mathrm{As}(\mathrm{III}) / \mathrm{As}(\mathrm{V})$ : reference materials; control: mineral-only experiments without bacteria; SBAG: bacteria, goethite and As(III) added simultaneously; BAG: bacteria added before goethite; GAB: goethite added before bacteria.).

Table 1

Linear combination fitting of As K edge XANES spectra for the samples.

\begin{tabular}{lcrlll}
\hline & Percentage, \% & & & & \\
\cline { 2 - 6 } Std & SBAG(goethite) & BAG & GAB & Hematite & Magnetite \\
\hline As(III) & 6.1 & 4.7 & 27.0 & 10.9 & - \\
As(V) & 93.9 & 95.3 & 73.0 & 89.1 & 100 \\
\hline
\end{tabular}

\subsection{Comparison of As(III) oxidation in three cell-iron oxide systems}

Three mixed cell-iron oxide batch experiments were conducted using As(III)-oxidizing bacteria with hematite, goethite and magnetite, separately. The amount of As in the aqueous phase after $10 \mathrm{~h}$ of incubation is shown in Fig. S3. In the presence of As(III)oxidizing bacteria, $\operatorname{As}(\mathrm{V})$ was the predominant species in the aqueous phase. As speciation on iron oxides was determined with XANES analysis. The XANES results revealed that $\mathrm{As}(\mathrm{III})$ was the only species on the iron oxides in the abiotic control experiments (data not shown). As(V) was the predominant species on iron oxides in the cell-iron oxide experimental group(Fig. 5). The ratio of As(III) to total As after incubation decreased in the following order: hematite $(10.9 \%)>$ goethite $(6.1 \%)>$ magnetite $(0)$ (Table 1$)$. Based on the analysis of As concentration in aqueous solution, the results indicated that with the maximal adsorption capacity, less $\mathrm{As}(\mathrm{V})$ was observed on the surface of hematite than that on the surface of goethite and magnetite at the end of incubation. This result provides additional evidence of a faster oxidation rate in the aqueous phase than in the solid phase by Pseudomonas sp. HN-1. Another possible reason of this result is that arsenic forms different structures with the iron oxides. It is reported that As(III) forms different inner-sphere surface complex on hematite and goethite (OnaNguema et al., 2005), which might made adsorbed As(III) on hematite a little more difficult to be oxidized.

According to mechanisms of $\mathrm{As}(\mathrm{V})$ reduction in solid phase (Huang et al., 2011b; Ohtsuka et al., 2013), there might be two explanations of $\mathrm{As}(\mathrm{III})$ oxidation in solid phase: one is directly oxidation of $\mathrm{As}(\mathrm{III})$ in solid phase; one is that the attachment of cells promoted As(III) desorption, and the desorbed As(III) was oxidized followed by adsorption of $\mathrm{As}(\mathrm{V})$ on the solid phase (Dong et al.,

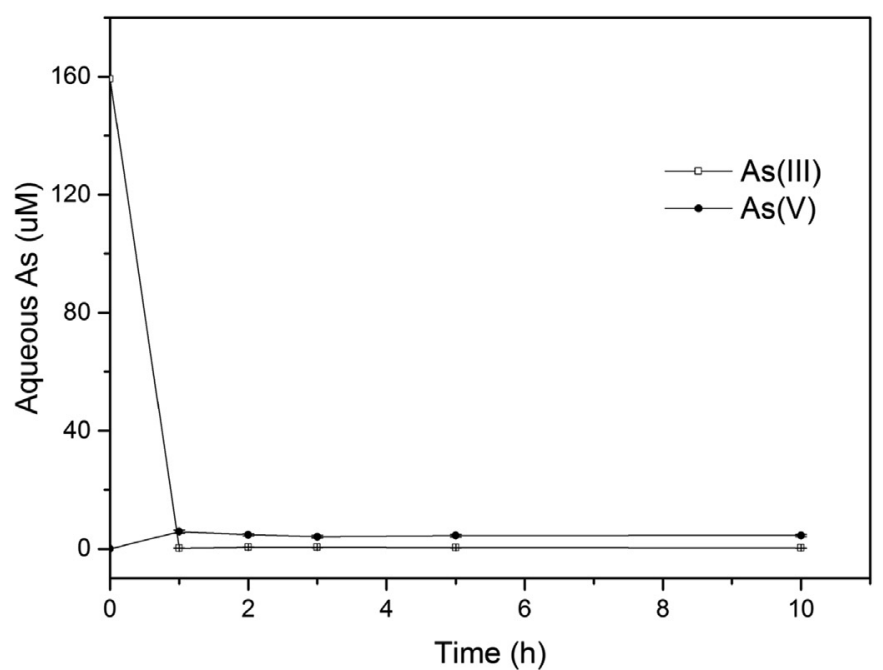

(a)

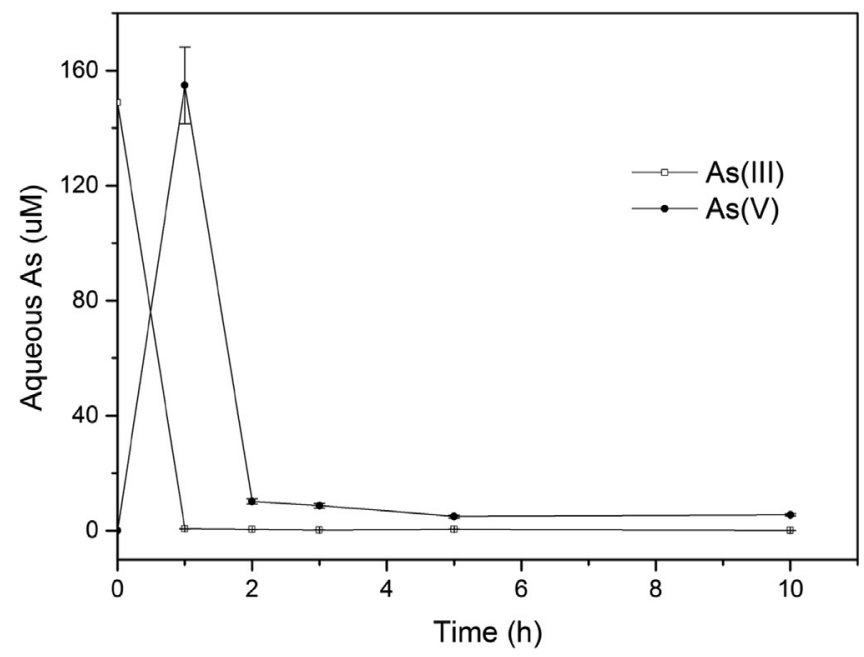

(b)

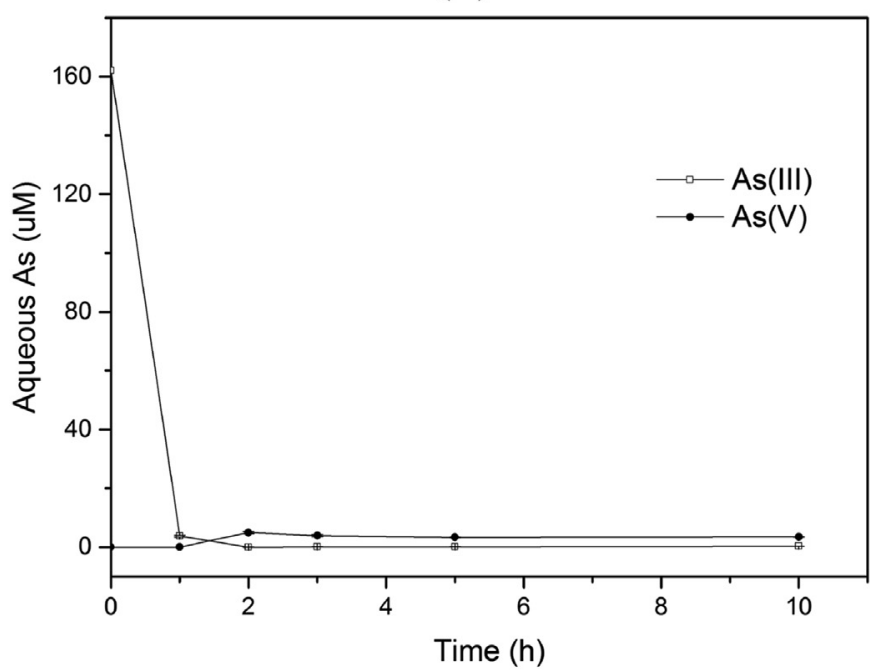

(c)

Fig. 4. Concentration of dissolved $\mathrm{As}(\mathrm{III})$ and $\mathrm{As}(\mathrm{V})$ during incubation of (a) SBAG, (b) BAG and (c) GAB. 


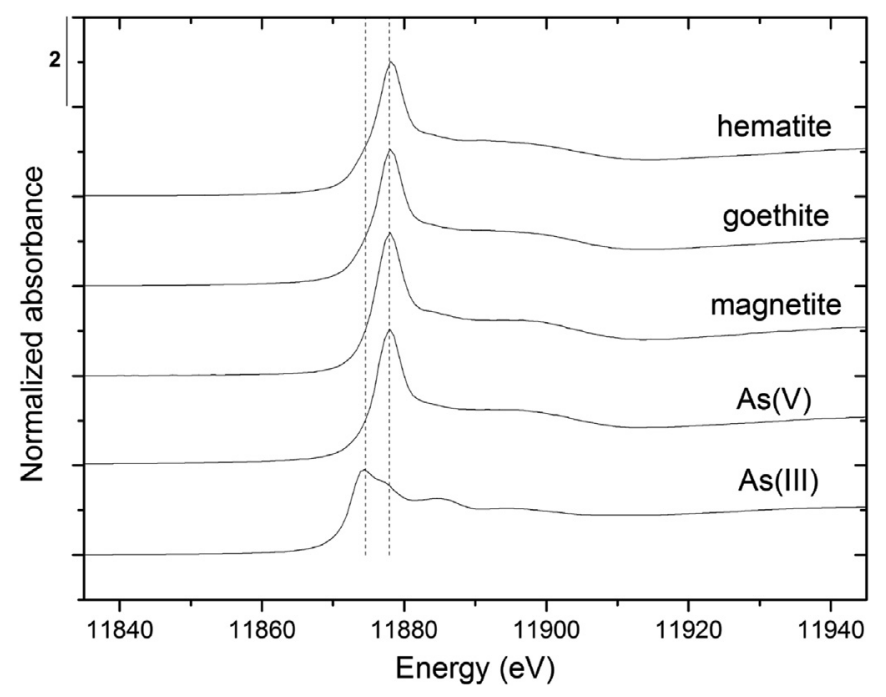

Fig. 5. Arsenic K-edge XANES data for $\mathrm{As}(\mathrm{III})$ and $\mathrm{As}(\mathrm{V})$ adsorbed onto hematite, goethite and magnetite at the end of incubation.

2014). So far, only oxygen, nitrate or chlorate reduction have been shown to be coupled to As(III) oxidation in the chemolithotrophs (Oremland et al., 2009). And oxygen has been shown to be coupled to $\mathrm{As}$ (III) oxidation in the heterotrophs. As(III) serves as an electron donor via the As(III) oxidase (Slyemi and Bonnefoy, 2012). For heterotrophic As(III) oxidizers, the oxidation of $\mathrm{As}(\mathrm{III})$ is described as a detoxification mechanism catalyzed by the periplasmic enzyme arsenite oxidase (Muller et al., 2003). Thus, As(III) was taken up into the periplasmic space, oxidized and released in the form of $\mathrm{As}(\mathrm{V})$ (Slyemi and Bonnefoy, 2012). The probability was greatly reduced for fixed $\mathrm{As}(\mathrm{III})$ to be taken up into periplasmic space, compared with free As(III). This might be one reason for the slower oxidation rate in the solid phase. The attachment of bacteria to minerals (Fig. 2) might reduce the contact between bacteria and As(III), thus reducing the oxidation of fixed As(III). As for the second explanation of $\mathrm{As}(\mathrm{III})$ oxidation in solid phase, the oxidation rate might be limited by low desorption concentration of As(III) (Huang et al., 2011b).

Therefore, minerals with a higher affinity for As(III) might offer greater obstacle for As(III) oxidation in soils. Parikh et al. demonstrated that various mineral surfaces could block Mn-oxide reaction sites, thus inhibiting As(III) oxidation (Zhu et al., 2009). Ehlert et al. implied that As(III) oxidation by birnessite could be inhibited by ferrihydrite (Ehlert et al., 2014). Thus, the valence state of As in soil is related to the mineralogical soil type. Regarding the remediation or removal of As from wastewater, oxidation by bacteria is recommended before adsorption by adsorbents, because oxidation in solid phase is slow. The inhibition of As(III) oxidation was caused by minerals with no oxidizing ability. However, in the presence of minerals with oxidizing ability, facilitation of As oxidation was dominant instead of inhibition. In the study of Jones et al., The apparent rate of $\mathrm{As}(\mathrm{III})$ oxidation rate was greater for the combined batch experiments in which bacteria and $\delta-\mathrm{MnO}_{2}$ were oxidizing $\mathrm{As}(\mathrm{III})$ at the same time than for either component alone (Jones et al., 2012).

\section{Conclusion}

In the presence of As(III)-oxidizing bacteria and iron oxides, $\mathrm{As}(\mathrm{V})$ is the primary form of inorganic As in the solid and aqueous phases under aerobic conditions. In addition, we found that the interaction between Pseudomonas sp. $\mathrm{HN}-1$ cells and mineral sorbents lowered the total As adsorption by minerals. Our results demonstrated that microbial oxidation proceeded much more slowly in solid phase than in the aqueous phase. The adsorption of As(III) onto mineral surfaces strongly reduced the rate of $\mathrm{As}(\mathrm{III})$ oxidation. Furthermore, this study showed that minerals with a higher affinity for As(III) offered greater obstacle for As(III) oxidation in soils. Therefore, the valence state of As in soil is related to the mineralogical soil type.

\section{Acknowledgments}

We acknowledge the National Natural Science Foundation of China (No. 41571451) and Special Funds for Science and Education Fusion of University of Chinese Academy of Sciences for providing financial support of this research. We thank Yue Li for her effort in proofreading this article. We also thank the Beijing Synchrotron Radiation Facility (BSRF) for the valuable beamtime.

\section{Appendix A. Supplementary data}

Supplementary data related to this article can be found at http:// dx.doi.org/10.1016/j.chemosphere.2016.02.065.

\section{References}

Amstaetter, K., Borch, T., Larese-Casanova, P., Kappler, A., 2010. Redox transformation of arsenic by Fe(II)-activated goethite (alpha-FeOOH). Environ. Sci. Technol. 44, 102-108.

Arai, Y., Sparks, D.L., Davis, J.A., 2004. Effects of dissolved carbonate on arsenate adsorption and surface speciation at the hematite-water interface. Environ. Sci. Technol. 38, 817-824.

Bahar, M.M., Megharaj, M., Naidu, R., 2012. Arsenic bioremediation potential of a new arsenite-oxidizing bacterium Stenotrophomonas sp. MM-7 isolated from soil. Biodegradation 23, 1-10.

Bhandari, N., Reeder, R.J., Strongin, D.R., 2011. Photoinduced oxidation of arsenite to arsenate on ferrihydrite. Environ. Sci. Technol. 45, 2783-2789.

Bhandari, N., Reeder, R.J., Strongin, D.R., 2012. Photoinduced oxidation of arsenite to arsenate in the presence of goethite. Environ. Sci. Technol. 46, 8044-8051.

Cai, L., Liu, G., Rensing, C., Wang, G., 2009. Genes involved in arsenic transformation and resistance associated with different levels of arsenic-contaminated soils. BMC Microbiol. 9.

Cullen, W.R., Reimer, K.J., 1989. Arsenic speciation in the environment. Chem. Rev. 89, 713-764.

Daus, B., Weiss, H., Wennrich, R., 1998. Arsenic speciation in iron hydroxide precipitates. Talanta 46, 867-873.

Dong, D.T., Yamaguchi, N., Makino, T., Amachi, S., 2014. Effect of soil microorganisms on arsenite oxidation in paddy soils under oxic conditions. Soil Sci. Plant Nutr. 60, 377-383.

Eary, L.E., Janet, A.S., 1990. Rates of Inorganic Oxidation Reactions Involving Dissolved Oxygen. Chemical Modeling of Aqueous Systems II. American Chemical Society, pp. 379-396.

Ehlert, K., Mikutta, C., Kretzschmar, R., 2014. Impact of birnessite on arsenic and iron speciation during microbial reduction of arsenic-bearing ferrihydrite. Environ. Sci. Technol. 48, 11320-11329.

Elsner, M., Schwarzenbach, R.P., Haderlein, S.B., 2004. Reactivity of Fe(II)-bearing minerals toward reductive transformation of organic contaminants. Environ. Sci. Technol. 38, 799-807.

Fang, L., Cao, Y., Huang, Q., Walker, S.L., Cai, P., 2012. Reactions between bacterial exopolymers and goethite: a combined macroscopic and spectroscopic investigation. Water Res. 46, 5613-5620.

Frommer, J., Voegelin, A., Dittmar, J., Marcus, M.A., Kretzschmar, R., 2011. Biogeochemical processes and arsenic enrichment around rice roots in paddy soil: results from micro-focused X-ray spectroscopy. Eur. J. Soil Sci. 62, 305-317.

Gimenez, J., Martinez, M., de Pablo, J., Rovira, M., Duro, L., 2007. Arsenic sorption onto natural hematite, magnetite, and goethite. J. Hazard. Mater 141, 575-580.

Hong, Z., Chen, W., Rong, X., Cai, P., Dai, K., Huang, Q., 2013. The effect of extracellular polymeric substances on the adhesion of bacteria to clay minerals and goethite. Chem. Geol. 360, 118-125.

Huang, J.-H., Elzinga, E.J., Brechbuchl, Y., Voegelin, A., Kretzschmar, R., 2011a. Impacts of Shewanella putrefaciens strain $\mathrm{CN}-32$ cells and extracellular polymeric substances on the sorption of $\mathrm{As}(\mathrm{V})$ and $\mathrm{As}(\mathrm{III})$ on Fe(III)-(Hydr)oxides. Environ. Sci. Technol. 45, 2804-2810.

Huang, J.-H., Voegelin, A., Pombo, S.A., Lazzaro, A., Zeyer, J., Kretzschmar, R., 2011b. Influence of arsenate adsorption to ferrihydrite, goethite, and boehmite on the kinetics of arsenate reduction by Shewanella putrefaciens strain CN-32. Environ. Sci. Technol. 45, 7701-7709.

Jolivet, J.P., Tronc, E., 1988. Interfacial electron-transfer IN colloidal spinel iron-oxide 
- conversion of $\mathrm{Fe}_{3} \mathrm{O}_{4}$-gamma- $\mathrm{Fe}_{2} \mathrm{O}_{3}$ IN aqueous-medium. J. Colloid Interface Sci. $125,688-701$.

Jones, L.C., Lafferty, B.J., Sparks, D.L., 2012. Additive and competitive effects of bacteria and Mn oxides on arsenite oxidation kinetics. Environ. Sci. Technol. 46, 6548-6555.

Lakshmipathiraj, P., Narasimhan, B.R.V., Prabhakar, S., Raju, G.B., 2006. Adsorption of arsenate on synthetic goethite from aqueous solutions. J. Hazard. Mater 136, 281-287.

Lane, D., 1991. In: Stackebrandt, E., Goodfellow, M. (Eds.), 16S/23S rRNA Sequencing. Nucleic Acid Techniques in Bacterial Systematics. Wiley, West Sussex, England, pp. 115-175.

Langner, H.W., Inskeep, W.P., 2000. Microbial reduction of arsenate in the presence of ferrihydrite. Environ. Sci. Technol. 34, 3131-3136.

Liao, V.H., Chu, Y., Su, Y., Hsiao, S., Wei, C., Liu, C., Liao, C., Shen, W., Chang, F., 2011. Arsenite-oxidizing and arsenate-reducing bacteria associated with arsenic-rich groundwater in Taiwan. J. Contam. Hydrol 123, 20-29.

Liu, S.X., Athar, M., Lippai, I., Waldren, C., Hei, T.K., 2001. Induction of oxyradicals by arsenic: implication for mechanism of genotoxicity. Proc. Natl. Acad. Sci. 98, $1643-1648$.

Morin, G., Juillot, F., Casiot, C., Bruneel, O., Personne, J.C., Elbaz-Poulichet, F. Leblanc, M., Ildefonse, P., Calas, G., 2003. Bacterial formation of tooeleite and mixed Arsenic(III) or Arsenic(V)-Iron(III) gels in the carnoulbs acid mine drainage, France. A XANES, XRD, and SEM study. Environ. Sci. Technol. 37, 1705-1712.

Muehe, E.M., Scheer, L., Daus, B., Kappler, A., 2013. Fate of arsenic during microbial reduction of biogenic versus abiogenic As-Fe(III)-Mineral coprecipitates. Environ. Sci. Technol. 47, 8297-8307.

Muller, D., Lièvremont, D., Simeonova, D.D., Hubert, J.-C., Lett, M.-C., 2003. Arsenite oxidase aox genes from a metal-resistant $\beta$-proteobacterium. J. Bacteriol. 185, 135-141.

Ohe, K., Oshima, T., Baba, Y., 2010. Adsorption of arsenic using high surface area magnetites. Environ. Geochem. Health 32, 283-286.

Ohtsuka, T., Yamaguchi, N., Makino, T., Sakurai, K., Kimura, K., Kudo, K., Homma, E., Dong, D.T., Amachi, S., 2013. Arsenic dissolution from Japanese paddy soil by a dissimilatory arsenate-reducing bacterium geobacter sp OR-1. Environ. Sci. Technol. 47, 6263-6271.

Omoike, A., Chorover, J., 2006. Adsorption to goethite of extracellular polymeric substances from Bacillus subtilis. Geochim. Cosmochim. Acta 70, 827-838.

Ona-Nguema, G., Morin, G., Juillot, F., Calas, G., Brown, G.E., 2005. EXAFS analysis of arsenite adsorption onto two-line ferrihydrite, hematite, goethite, and lepidocrocite. Environ. Sci. Technol. 39, 9147-9155.
Ona-Nguema, G., Morin, G., Wang, Y., Foster, A.L., Juillot, F., Calas, G., Brown Jr., G.E., 2010. XANES evidence for rapid Arsenic(III) oxidation at magnetite and ferrihydrite surfaces by dissolved O-2 via Fe2+-mediated reactions. Environ. Sci. Technol. 44, 5416-5422.

Oremland, R.S., Saltikov, C.W., Wolfe-Simon, F., Stolz, J.F., 2009. Arsenic in the evolution of earth and extraterrestrial ecosystems. Geomicrobiol. J. 26, $522-536$.

Oremland, R.S., Stolz, J.F., 2003. The ecology of arsenic. Science 300, 939-944.

Oremland, R.S., Stolz, J.F., 2005. Arsenic, microbes and contaminated aquifers. Trends Microbiol. 13, 45-49.

Parikh, S.J., Lafeerty, B.J., Meade, T.G., Sparks, D.L., 2010. Evaluating environmental influences on as-III oxidation kinetics by a poorly crystalline Mn-oxide. Environ. Sci. Technol. 44, 3772-3778.

Post, J.E., 1999. Manganese oxide minerals: crystal structures and economic and environmental significance. Proc. Natl. Acad. Sci. U. S. A. 96, 3447-3454.

Santini, J.M., Sly, L.I., Schnagl, R.D., Macy, J.M., 2000. A new chemolithoautotrophic arsenite-oxidizing bacterium isolated from a gold mine: phylogenetic, physiological, and preliminary biochemical studies. Appl. Environ. Microbiol. 66, 92-97.

Schwertmann, U., Cornell, R.M., 1991. Iron Oxides in the Laboratory: Preparation and Characterization. Wiley-VCH, Weinheim,Germany.

Slyemi, D., Bonnefoy, V., 2012. How prokaryotes deal with arsenic. Environ. Microbiol. 4, 571-586.

Smedley, P.L., Kinniburgh, D.G., 2002. A review of the source, behaviour and distribution of arsenic in natural waters. Appl. Geochem 17, 517-568.

Smith, E., Naidu, R., Alston, A.M., 1998. Arsenic in the soil environment: a review. Adv. Agron. 64, 149-195.

Wang, Y., Xu, J., Zhao, Y., Zhang, L., Xiao, M., Wu, F., 2013. Photooxidation of arsenite by natural goethite in suspended solution. Environ. Sci. Pollut. Res. 20, 31-38.

Weeger, W., Lievremont, D., Perret, M., Lagarde, F., Hubert, J.C., Leroy, M., Lett, M.C., 1999. Oxidation of arsenite to arsenate by a bacterium isolated from an aquatic environment. Biometals 12, 141-149.

WorldHealthOrganization, 1981. Environmental Health Criteria 18; Arsenic. World Health Organization, Geneva.

Zhu, M., Paul, K.W., Kubicki, J.D., Sparks, D.L., 2009. Quantum chemical study of arsenic (III, V) adsorption on Mn-oxides: implications for Arsenic(III) oxidation. Environ. Sci. Technol. 43, 6655-6661.

Zhu, Y.G., Sun, G.X., Lei, M., Teng, M., Liu, Y.X., Chen, N.C., Wang, L.H., Carey, A.M., Deacon, C., Raab, A., Meharg, A.A., Williams, P.N., 2008. High percentage inorganic arsenic content of mining impacted and nonimpacted Chinese rice. Environ. Sci. Technol. 42, 5008-5013. 